\title{
Down regulation of epidermal growth factor receptors in liver proliferation induced by a mixture of triiodothyronine, amino acids, glucagon, and heparin (TAGH)
}

Gastroenterology Unit, Department of Medicine, Royal Postgraduate Medical School, London D A Vesey A C Selden H J F Hodgson Correspondence to: Professor H J F Hodgson, Gastroenterology Unit, Department of Medicine,
Royal Postgraduate Medical Royal Postgraduate Med, London W12 0NN.

Accepted for publication 10 March 1993

\author{
D A Vesey, A C Selden, H J F Hodgson
}

\begin{abstract}
This study investigated the mechanisms by which TAGH solution (a mixture of triiodothyronine, amino acids, glucagon, and heparin) induces DNA synthesis in hepatocytes in the liver of intact rats, with particular reference to events at the epidermal growth factor (EGF) receptor. Both partial hepatectomy and infusion of TAGH stimulated DNA synthesis at 24 hours and both procedures resulted in a reduction of EGF receptors assessed in plasma membranes isolated from rat liver at this time. In cell cultures, while EGF strongly stimulated DNA synthesis and started EGF receptor down regulation, TAGH had only a minor effect $(1.5 \times$ basal $)$ on DNA synthesis and did not interact with or down regulate the EGF receptor. Membrane phosphorylation studies, however, showed that TAGH induced phosphorylation of tyrosine residues in the EGF receptor. The in vivo action of TAGH seems to entail recruitment of similar changes in the EGF receptor to those that occur after partial hepatectomy.

(Gut 1993; 34: 1601-1606)
\end{abstract}

The factors controlling hepatocyte proliferation are complex and incompletely understood.' Prominent events at the hepatocyte membrane after induction of DNA synthesis in rat livers by partial hepatectomy include down regulation and phosphorylation of the epidermal growth factor (EGF) receptor. ${ }^{23}$ These events can also be seen when EGF is used to start DNA synthesis in hepatocytes in vitro. ${ }^{47}$ Ligand binding to the EGF receptor therefore seems to be integrally associated with liver cell proliferation.

Short et $a l^{8}$ described the action of TAGH solution - a mixture of triiodothyronine, amino acids, glucagon and heparin - as an initiator of DNA synthesis, hepatocyte mitosis, and also causing an increase in liver size in intact rats. The time course of DNA synthesis after the start of the infusion was the same as that following $70 \%$ hepatectomy, enhancement of DNA formation occurring within 15 hours. The mechanism of action of TAGH has not been elucidated. As the constituents of TAGH solution are readily available as pharmaceutical preparations, this offers a potential treatment for severe liver diseases in which hepatic regeneration would be beneficial. We therefore investigated the mode of action of TAGH by comparing in vivo and in vitro phenomena induced in hepatocytes by EGF and TAGH. The findings show that in vivo TAGH results in EGF receptor down regulation; in in vitro hepatocyte cultures TAGH does not induce EGF receptor down regulation, although it was capable of inducing phosphorylation of tyrosine residues of the EGF receptor in liver plasma membrane preparations in vitro.

\section{Materials and methods}

ANIMALS

All experiments were performed on male August rats (250-300 g) (National Institute of Medical Research, Mill Hill, London, UK), and all procedures were carried out between 900 am and noon.

Seventy per cent hepatectomy was performed as described by Higgins and Anderson ${ }^{9}$ under ether anaesthetic. Sham operations consisted of laparotomy and gentle manipulation of the liver.

The TAGH solution $(9 \mathrm{ml})$ was made up fresh at the time of the experiment and infused by the tail vein from $20 \mathrm{ml}$ hyperdermic syringes mounted in horizontal syringe pumps set to deliver $3 \mathrm{ml} / \mathrm{h}$. The TAGH solution consisted of $100 \mu \mathrm{g}$ of triiodothyronine $(200 \mu \mathrm{l}), 1 \mathrm{mg}$ of glucagon $(1 \mathrm{ml}), 100$ units of heparin $(100 \mu \mathrm{l})$ and $7.7 \mathrm{ml}$ of an amino acid mixture (Synthamin $\left.14^{\star}\right)$. Synthamin $14^{\star}$ is a commercial mixture of nine essential and six non-essential L-amino acids $(8 \cdot 5 \% \mathrm{wt} / \mathrm{vol})$. The solution was adjusted to pH $7 \cdot 2$ with $0.01 \mathrm{M}$ sodium hydroxide.

\section{MATERIALS}

[6- $\left.{ }^{3} \mathrm{H}\right]$-Thymidine (specific activity 25-30 $\mathrm{Ci} / \mathrm{mmol}$ ) and carrier free $\mathrm{Na}^{125} \mathrm{I}$ were obtained from Amersham International PLC, Amersham, Bucks, UK. William's medium E, fetal bovine serum (FBS), penicillin/streptomycin, fungizone (amphotericin B), gentamycin, and Nunclon microwell plates were obtained from Gibco, Paisley, Renfrewshire, Scotland. Insulin (human monocomponent, actrapid) and glucagon were purchased from Novo, Copenhagen, Denmark. Triiodothyronine was from Sigma. Heparin was from Leo Labs Ltd, Princes Risborough, Bucks, UK. Collagenase (Clostridium histolyticum) was purchased from Boehringer Mannheim Ltd, Lewes, East Sussex, UK. The amino acid solution, Synthamin 14, was purchased from Travenol Laboratories Ltd, Compton, Berks, UK. Collaborative Research mouse EGF (tissue culture grade) was obtained from Universal Biologicals, London, UK. Other reagents and chemicals were from Sigma 
Chemical Company or BDH Chemicals, both of Poole, Dorset, UK.

IN VIVO ${ }^{3} \mathrm{H}$-THYMIDINE INCORPORATION

Rats received an intraperitoneal injection of ${ }^{3} \mathrm{H}$-thymidine $(0.5 \mu \mathrm{Ci} / \mathrm{g}$ body weight $)$ one hour before death. Twenty four hours after partial hepatectomy or the start of the TAGH infusion, rats were anaesthetised and the liver perfused in place with ice cold saline to remove excess blood. The liver was rapidly removed and placed on ice. A small section of liver was frozen for measurement of thymidine incorporation. The remaining tissue was used to prepare liver cell plasma membranes. ${ }^{3} \mathrm{H}$-thymidine incorporation into liver DNA was measured biochemically by a modification of the method of Munro and Fleck, ${ }^{10}$ as described in Vesey et al. ${ }^{11}$

ISOLATION AND CULTURE OF HEPATOCYTES

Adult rat hepatocytes were isolated using a modification of the Berry and Friend procedure, ${ }^{12}$ as described in Vesey et al 1992. ${ }^{11}$ Cells were resuspended at $3 \times 10^{5}$ or $2 \times 10^{5}$ viable cells $/ \mathrm{ml}$ in William's medium $\mathrm{E}$, without L-glutamine, supplemented with penicillin (200 $\mathrm{IU} / \mathrm{ml})$; streptomycin $(200 \mathrm{IU} / \mathrm{ml})$; gentamycin $(80 \mu \mathrm{g} / \mathrm{ml}) ;$ fungizone $(1.25 \mu \mathrm{g} / \mathrm{ml}) ; 5 \%$ (vol/vol) heat inactivated fetal bovine serum and dexamethazone $\left(10^{-8} \mathrm{M}\right)$ (plating medium) and seeded on rat tail collagen (type-1) coated Nunclon 24-well cluster trays or 96-well microtitre tissue culture plates, at densities of $7 \cdot 5 \times$ $10^{4} / \mathrm{cm}^{2}$ and at $6 \cdot 25 \times 10^{4} / \mathrm{cm}^{2}$ respectively.

\section{PLASMA MEMBRANE PREPARATION}

Rat liver plasma membranes prepared by the method of Aronson and Touster ${ }^{13}$ were resuspended in $5 \mathrm{mM}$ HEPES buffer $\mathrm{pH} 7.5$ at approximately $5 \mathrm{mg} / \mathrm{ml}$ and stored in liquid nitrogen until used. Protein concentrations were determined by a modification of the method of Lowry ${ }^{14}$ using BSA as a standard.

\section{IODINATION OF EGF}

EGF was iodinated by a modification of the chloramine-T method to give a specific activity of between 20 to $60 \mu \mathrm{Ci} / \mu \mathrm{g}$ as previously described. ${ }^{15}$

\section{EGF BINDING STUDIES}

On hepatocytes - binding studies on whole cells were carried out in 24 well cluster trays. ${ }^{11}$ For analysis of receptor numbers and affinity, cells were incubated with increasing amounts of ${ }^{125}$ I-EGF (30-4000 fmoles) for $2 \cdot 5$ hours, and non-specific binding determined at each point by inclusion of a $1-2 \mu \mathrm{g} / \mathrm{ml}$ of unlabelled EGF in replicate cultures. This was subtracted from total counts bound to obtain specific binding. Points represent the means of triplicate measurements.

On plasma membranes - increasing amounts of ${ }^{125}$ I-EGF (50-3000 fmoles) were incubated with between 60 and $100 \mu \mathrm{g}$ of membrane protein for
60 minutes. "Measurements were made in triplicate. Binding data were analysed and curves fitted using the GraphPAD Inplot computer program (San Diego, CA, USA).

\section{IN VITRO ${ }^{3} \mathrm{H}$-THYMIDINE INCORPORATION}

DNA synthesis was assessed in cultured hepatocytes by measurement of ${ }^{3} \mathrm{H}$-thymidine incorporation into cell DNA after stimulation with insulin $\left(10^{-7} \mathrm{M}\right)$ and EGF $(20 \mathrm{ng} / \mathrm{ml})$ or plating medium containing the dilutions of TAGH for 24 hours (see Tables). ${ }^{11}$ The amount, in quadruplicate, of ${ }^{3} \mathrm{H}$-thymidine incorporated was assessed biochemically as described by Selden and Hodgson. ${ }^{16}$

\section{EGF RECEPTOR PHOSPHORYLATION STUDIES}

Phosphorylation studies were carried out essentially as Rubin $e t$ al. $^{3}$ The reaction was performed at $0^{\circ} \mathrm{C}$ in a total volume of $50 \mu \mathrm{l}$, containing $50 \mu \mathrm{g}$ of membrane protein, $50 \mathrm{mM}$ Pipes at $\mathrm{pH}$ 7.0, $30 \mathrm{mM} \mathrm{MgCl}$, $10 \mathrm{mM}$ 2-mercaptoethanol, and $0.32 \mathrm{mM}$ ethylene glycol BIS-( $\beta$-aminoethyl ether) $\mathbf{N}, \mathbf{N}, \mathbf{N}^{\prime}, \mathbf{N}^{\prime}$-tetraacetic acid. Factors, EGF $\left(5 \mu \mathrm{g} / \mathrm{ml}\right.$ in $\left.\mathrm{H}_{2} \mathrm{O}\right)$, or $\mathrm{TAGH}$ solution $(10 \mu \mathrm{l})$, or water $(10 \mu \mathrm{l})$ as control were added to the tubes. After 15 minutes p reincubation at $0^{\circ} \mathrm{C}$ the reaction was started by addition of $15 \mu \mathrm{Ci}$ $(15 \mu \mathrm{l})$ of $\gamma^{32} \mathrm{P}$ ATP to a final concentration of $2 \mathrm{mM}$. It was stopped after one minute with 25 $\mu \mathrm{l}$ of $9 \%$ SDS sample buffer $(0 \cdot 0015 \%$ bromophenol blue, $10 \mathrm{ml}$ of $2 \%$ SDS, $25 \mathrm{mM}$ TRIS $\mathrm{pH}$ $6 \cdot 8$, and $20 \%$ sucrose). Tubes were sealed and heated for three minutes at $100^{\circ} \mathrm{C}$. Aliquots $(40 \mu \mathrm{l})$ were subjected to electrophoresis on $5 \%$ SDS PAGE slab gels.

\section{PHOSPHOAMINO ACID ANALYSIS}

The band corresponding to the EGF receptor was excised and the protein eluted from the gel strip in $0.05 \mathrm{M}$ ammonium bicarbonate containing SDS $(0 \cdot 1 \%)$ and $\beta$-mercaptoethanol $(5 \%)$ at

TABLE I DNA synthesis in the liver of rats after TAGH infusion

\begin{tabular}{lcc}
\hline Treatment & $\begin{array}{c}{ }^{3} \mathrm{H}-\text { Thymidine incorporation } \\
\left(\mathrm{d} p m \times 10^{-4} / \mathrm{g} \text { liver }\right)^{\star}\end{array}$ & No \\
\hline Saline & $7 \cdot 9(4 \cdot 8-11 \cdot 2)$ & 4 \\
Hepatectomy & $469(283-711)$ & 8 \\
TAGH & $63 \cdot 4(39-118)$ & 8 \\
\hline
\end{tabular}

$\star$ Mean (range).

${ }^{3} \mathrm{H}$-thymidine incorporation in rat liver 24 hours after infusion of TAGH compared with the response to hepatectomy. Thymidine was injected 1 hour before death at 24 hours. Data represent the means (range).

TABLE II EGF binding characteristics of plasma membranes isolated from whole liver 24 hours after $70 \%$ partial hepatectomy or TAGH infusion

\begin{tabular}{lll}
\hline & \multicolumn{3}{l}{ High affinity site } \\
\cline { 2 - 3 } Treatment & Bmax & $K_{D}$ \\
\hline Sham & $1138(132)$ & $1799(385)$ \\
Hepatectomy & $627(278)$ & $1690(278)$ \\
Saline & $1463(114)$ & $1520(231)$ \\
TAGH & $1165(90)$ & $1462(260)$ \\
\hline
\end{tabular}

Bmax values are given in fmoles/mg membrane protein (SEM) and those of the dissociation constant, $\mathrm{K}_{\mathrm{D}}$, in $\mathrm{pM}$ (SEM) 

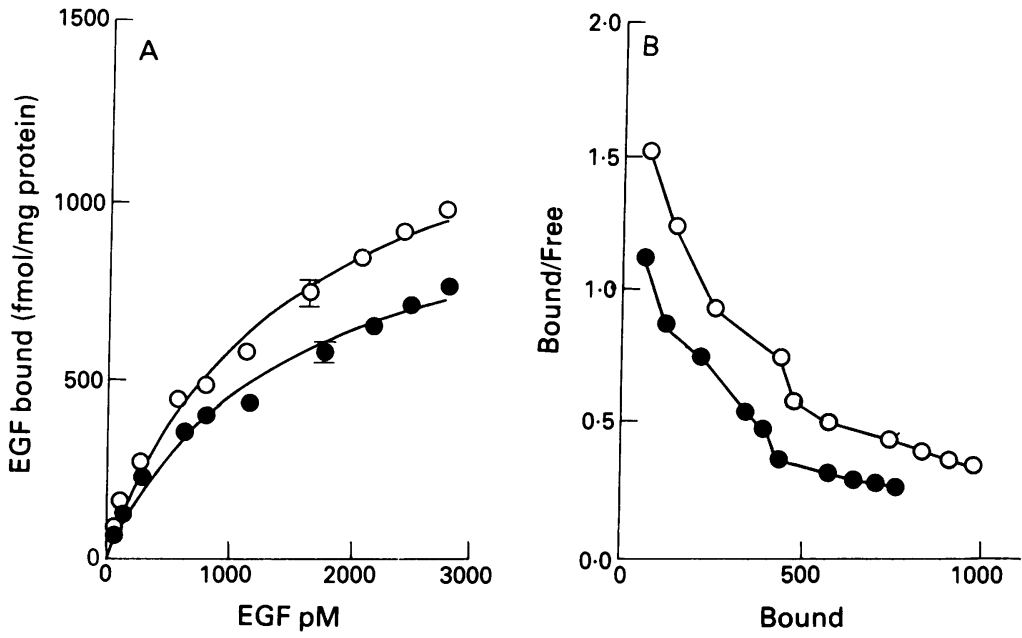

Figure 1: Effect of TAGH induced liver proliferation on liver plasma membrane EGF hours after the start of TAGH (O) or saline infusion $(O)$. Saturation binding curve $(A)$ and Scatchard analysis $(B)$. receptors. Plasma membranes were isolated by the method of Aronson and Touster ${ }^{13}$ from rats 24

TABLE III Down regulation of $E G F$ receptors; effect of time and $E G F$

\begin{tabular}{|c|c|c|c|c|c|}
\hline \multirow[b]{2}{*}{ Treatment } & \multicolumn{5}{|c|}{$\begin{array}{l}{ }^{125} I-E G F \text { bound (fmoles } / 10^{5} \text { cells) at } \\
\text { various times after start of treatment }(h)\end{array}$} \\
\hline & 1 & 5 & 10 & 22 & 42 \\
\hline Control & $\stackrel{24 \cdot 1}{(1 \cdot 6)}$ & $\begin{array}{l}24 \cdot 0 \\
(0 \cdot 4)\end{array}$ & $\begin{array}{c}16 \cdot 3 \\
(0 \cdot 7)\end{array}$ & $\begin{array}{l}8.9 \\
(0.2)\end{array}$ & $\begin{array}{r}5 \cdot 2 \\
(0 .\end{array}$ \\
\hline $\mathrm{EGF}(5 \mathrm{ng} / \mathrm{ml})$ & $\begin{array}{l}3.9 \\
(0 \cdot 2)\end{array}$ & $\begin{array}{l}4 \cdot 6 \\
(0 \cdot 4)\end{array}$ & $\begin{array}{r}4 \cdot 2 \\
(0 \cdot 2)\end{array}$ & $\begin{array}{l}3 \cdot 5 \\
(0 \cdot 1)\end{array}$ & $\begin{array}{l}3 \cdot 7 \\
(0 \cdot 1)\end{array}$ \\
\hline
\end{tabular}

Cells were plated on collagen coated 24 well plates and allowed to adhere for 2 hours. At this time fresh medium with or without EGF $(5 \mathrm{ng} / \mathrm{ml})$ was added to the cells. At various times binding assays were performed on the cells. ${ }^{125}$ I-EGF at $3 \mathrm{nM}$ was used. All cells received an acid wash before the binding assay. Numbers represent the mean $(\mathrm{SD})$ of quadruplicate measurements from represent the mean $(\mathrm{SD})$ of quadruplicate measurements from a typical experiment. Qualitatively

The well described fall in EGF receptor numbers after partial hepatectomy was confirmed. Scatchard analysis (Table II) of binding data (not shown) show a $45 \%$ reduction 24 hours after a $70 \%$ hepatectomy. An infusion of TAGH reduced ${ }^{125}$ I-EGF binding to liver plasma membranes, isolated 24 hours after the start of infusion, by $20 \%$ compared with saline (Fig 1). Table II shows the EGF binding parameters of these membranes. ample dissolved in a mixture of the phosphoamino acids, phosphoserine, phosphothreonine, and phosphotyrosine. The phosphoamino acids were separated by high voltage thin layer chromatography on cellulose plates in a mixture of pyridine, acetic acid, and water in the ratio 5:50:945 for 1000 volt hours. Standards were visualised with ninhydrin and the radioactive phosphoamino acids by autoradiography.

\section{Results}

IN VIVO STUDIES

Liver cell proliferation was stimulated in vivo by both $70 \%$ partial hepatectomy and by an intravenous infusion of $9 \mathrm{ml}$ of TAGH solution over three hours. The mean increase in incorporation of ${ }^{3} \mathrm{H}$-thymidine into liver compared with controls was 60 -fold 24 hours after partial hepatectomy and eightfold after TAGH infusion (Table I).
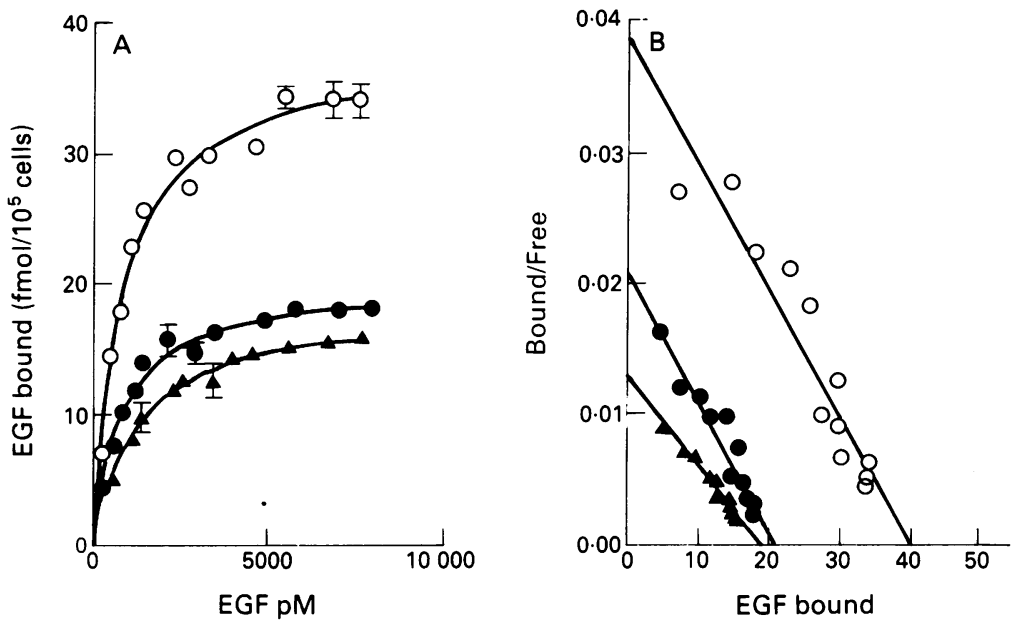

Figure 2: Effect of time in culture on hepatocyte cell surface EGF receptors. (A) Specific binding of increasing concentrations of ${ }^{125} I-E G F$ by primary hepatocytes in culture at $5(O)$ $22(\mathbf{O})$, and $30 h(\boldsymbol{\Delta})$ after plating. $(B)$ Scatchard analysis of binding data.

\section{IN VITRO STUDIES - HEPATOCYTE CULTURES}

Primary cultures of adult hepatocytes showed EGF binding, but with a progressive reduction with time in culture (Fig 2). Although there is a slight reduction in the number of cells per well over the culture period this could not account for the reduction in EGF binding seen. During the period from five to 30 hours in culture the number of receptors per cell fell from $2 \cdot 3 \times 10^{5}$ to

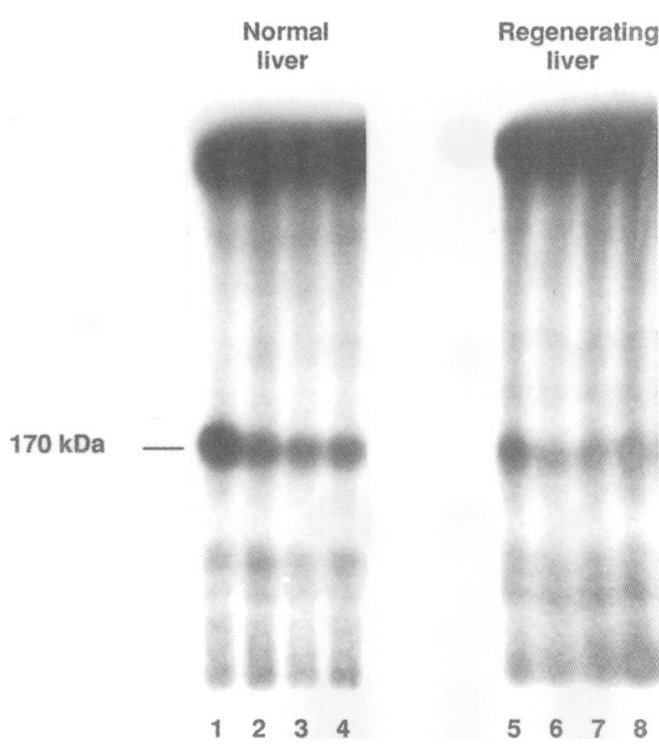

Figure 3: Autoradiograph of phosphorylated liver plasma hepatectomised rats. Membrane phosphorylation was carried out as described in the methods after preincubation with $E G F$ water, or insulin. Protein ( $35 \mu \mathrm{\mu g} /$ well) was subjected to SDS
$P A G E$ on a $5 \%$ slab gel (Laemmli discontinuous buffer, $p H$ $8 \cdot 3$ ) and the gel autoradiographed for $1 \cdot 5$ hours at $-70^{\circ} \mathrm{C}$. Lanes 1-4 control membranes, lanes 5-8 membranes from animals 24 hours after hepatic resection. Lanes 1 and 5; $5 \mu \mathrm{g} / \mathrm{ml} E G F$, lanes 2 and $6 ; 20 \mathrm{ng} / \mathrm{ml} \mathrm{EGF}$, lanes 3 and 7 ; insulin $10 \mu M$, lanes 4 and $8 ; 10 \mu$ l water. membrane proteins from sham operated and partially 


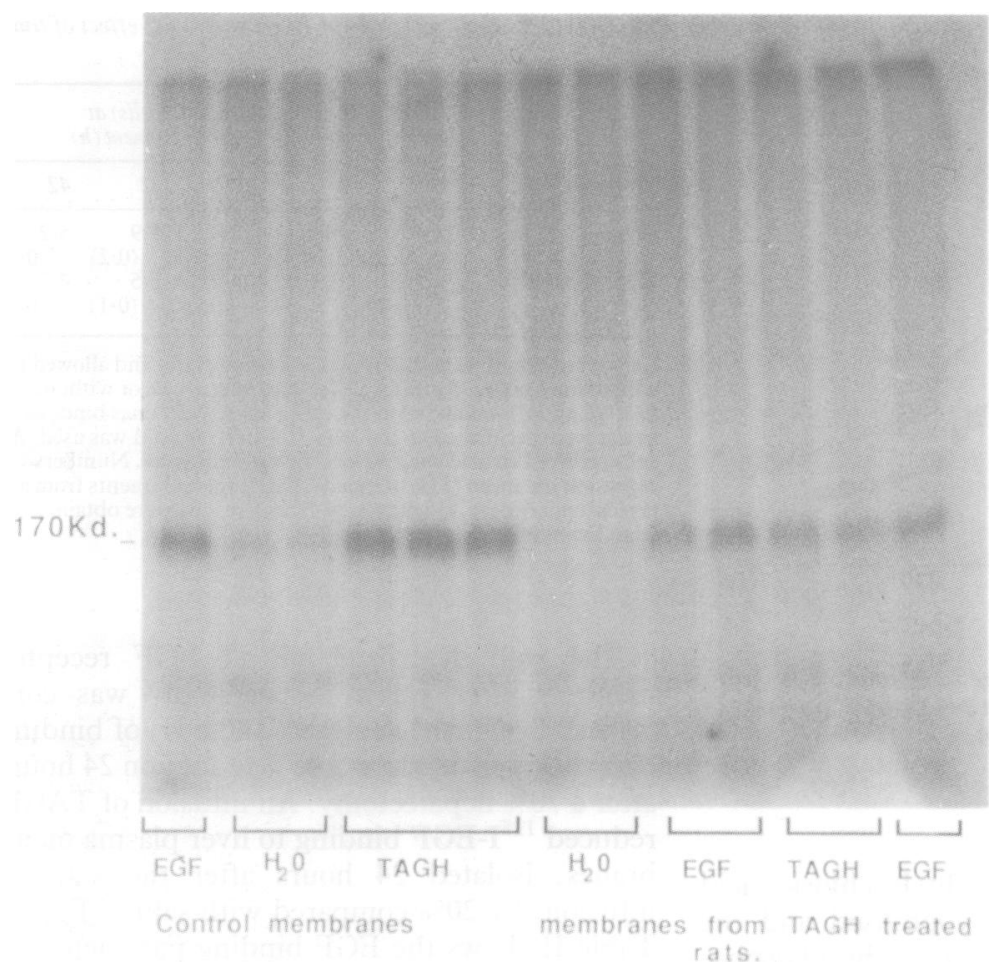

Figure 4: Effect of EGF and TAGH on phosphorylation of the EGF receptor in liver plasma membranes from TAGH treated and control rats. TAGH $(10 \%), E G F(5 \mu g / m l) .30 \mu g$ protein loaded per well. Gel was exposed to photographic film for one hour at $-70^{\circ} \mathrm{C}$.

Figure 5: Autoradiograph of ${ }^{32}$ P-labelled phosphoamino acids in normal rat liver plasma membrane EGF receptors preincubated with $E G F, T A G H$, or water. Phospho-serine, -tyrosine, and -threonine were separated along side as standards and visualised with ninhydrin.
TABLE IV DNA synthesis in hepatocytes in primary culture in response to TAGH

\begin{tabular}{lc}
\hline Treatment & $\begin{array}{c}3 \mathrm{H}-\text { Thymidine incorporation } \\
\left(d p m \times 10^{-3} / 2 \times 10^{4} \text { cells }\right)^{\star}\end{array}$ \\
\hline No addition & $30(6)$ \\
EGF+Insulin & $108 \cdot 6(18)$ \\
TAGH 1/10 & $27 \cdot 5(2 \cdot 0)$ \\
TAGH 1/100 & $30 \cdot 9(1 \cdot 7)$ \\
TAGH 1/200 & $35 \cdot 0(2 \cdot 6)$ \\
TAGH 1/500 & $41 \cdot 6(4 \cdot 1)$ \\
TAGH 1/1000 & $47 \cdot 7(3 \cdot 5)$ \\
TAGH 1/5000 & $50 \cdot 9(2 \cdot 5)$ \\
TAGH 1/10 000 & $50 \cdot 1(7 \cdot 9)$ \\
TAGH $1 / 10000+$ EGF & $98 \cdot 4(17)$ \\
EGF+Insulin+TAGH $1 / 10000$ & $135 \cdot 8(32)$
\end{tabular}

Values are the mean and SD of three measurements of a representative experiment. ${ }^{\star} n=3$.

TABLE V Effect of TAGH on cultured hepatocyte cell surface ${ }_{125}$ I-E GF binding

\begin{tabular}{lllll}
\hline & \multicolumn{4}{l}{ Time preincubated with } \\
\cline { 2 - 5 } Treatment & 2 & 5 & 15 & 23 \\
\hline Control & $21(0 \cdot 8)$ & $18(1)$ & $16(0 \cdot 9)$ & $10(0 \cdot 3)$ \\
TAGH 1/5000 & $18(1 \cdot 1)$ & $18(0 \cdot 7)$ & $15(0 \cdot 7)$ & $11(0 \cdot 2)$ \\
\hline
\end{tabular}

Mean (SD) from six measurements, $n=2$. TAGH solution was made up in $9 \mathrm{ml}$ and diluted in medium to give the dilutions made up.

a typical increase in DNA synthesis of eight to 12 -fold over basal in the presence of $10 \mathrm{ng} / \mathrm{ml}$ EGF.

Addition of TAGH to hepatocytes in culture gave a low level of stimulation of DNA synthesis which did not exceed $1.5 \times$ basal at any concentrations tested (Table IV). TAGH did not compete with binding of labelled EGF, or start down regulation of the EGF receptor on the isolated cells (Table V).

Addition of exogenous EGF to cultured cells resulted in down regulation of the receptors (Table III). The stimulatory effect of EGF in the dose range was confirmed (data not shown), with

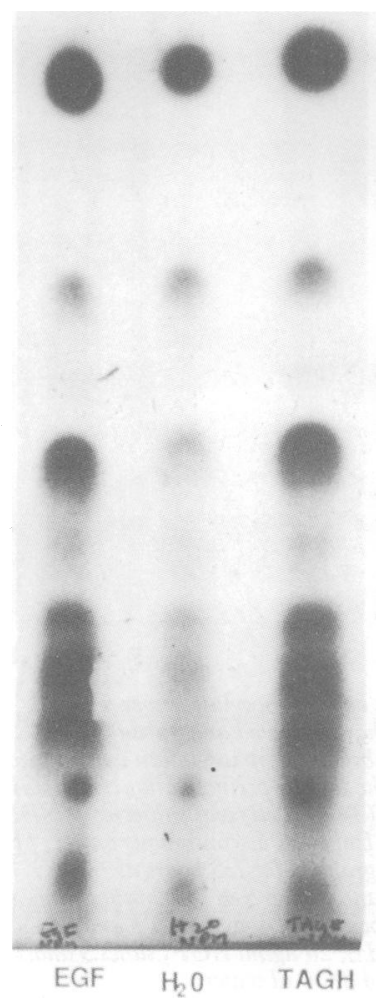

\section{MEMBRANE PHYOSPHORYLATION STUDIES}

The ability of EGF to induce autophosphorylation of the EGF receptor in plasma membranes isolated from normal rat liver and liver membranes of animals 24 hours after partial hepatectomy and TAGH infusion was compared. Incubation of normal membranes with EGF $(5 \mu \mathrm{g} / \mathrm{ml})$ in the presence of $\gamma^{32} \mathrm{P}$ labelled ATP, induced a striking enhancement of phosphorylation of the $170 \mathrm{kDa}$ band corresponding to the EGF receptor. Less noticeable phosphorylation of the receptor was seen in response to EGF in liver plasma membranes isolated 24 hours after partial hepatectomy and in TAGH infusion (Figs 3 and 4).

Normal plasma membranes were exposed to TAGH to investigate its effects on membrane phosphorylation. TAGH ( $1 / 10$ dilution) induced a similar degree of phosphorylation of the $170 \mathrm{kDa}$ band as was induced by EGF (Fig 4).

There was no evidence of enhanced phosphorylation of proteins at other molecular weights by TAGH. Phosphoamino acid analysis performed on acid hydrolysates of the phosphorylated $170 \mathrm{kDa}$ band, showed that both EGF and TAGH specifically induced phosphorylation of tyrosine residues (Fig 5).

Discussion

A substantial body of evidence implicates events 
at the EGF receptor as the start of hepatocyte proliferation after partial hepatectomy. EGF can start liver DNA synthesis when infused into intact rats ${ }^{17}$ and when added to primary hepatocyte in cultures ${ }^{16}$ - these events are associated with EGF receptor phosphorylation and down regulation $^{2-57}$; EGF given to partially hepatectomised rats is targeted in enhanced amounts to the nucleus - the site of maximum hepatic uptake corresponds to those areas of the liver where regeneration is most active ${ }^{18}$; partial hepatectomy results in substantial down regulation of the EGF receptor. ${ }^{2}$ Recent studies have suggested that in vivo, at the time of partial hepatectomy, the ligand responsible for down regulation of the EGF is in fact TGF $\alpha$, which is synthesised in the liver immediately after partial hepatectomy, and is a powerful hepatic mitogen via the EGF receptor. ${ }^{19-21}$

In this study we have induced hepatocyte DNA synthesis in the intact liver with an infusion of TAGH, and shown similar changes in the EGF receptor to those occurring after partial resection. Both partial hepatectomy and TAGH infusion lead to EGF receptor down regulation shown by reduced binding of EGF to liver plasma membranes isolated 24 hours later. In studies on such membranes isolated after partial hepatectomy or TAGH infusion, EGF induced less receptor phosphorylation than in normal membranes: reduced EGF induced autophosphorylation of the EGF receptor in membranes from the livers of hepatectomised rats has previously been attributed to the reduced receptor density on such membranes. ${ }^{3}$ These findings suggest TAGH infusion leads to a similar process of EGF receptor phosphorylation and internalisation as occurs after partial hepatectomy.

One hypothesis for the similarity of the events started by TAGH and liver resection at the EGF receptor is that TAGH (or a component thereof) directly interacts with the EGF receptor at the hepatocyte membrane. In cell culture conditions, however, in which exogenous EGF can readily be shown to down regulate its receptor and start hepatocyte DNA synthesis, TAGH showed no ability to down regulate the receptor, nor did it competitively inhibit EGF binding. Thus the modest increase in DNA synthesis started in hepatocyte cultures by TAGH $(1: 5000)$ is of similar magnitude to that reported for triiodothyronine alone ${ }^{17}$ and must act by a pathway other than that of direct interaction with the EGF binding site of the EGF receptor.

One shortcoming of the experiments reported here is that the effect of TAGH in inducing phosphorlyation of membranes in vitro was only detected at high doses of TAGH. The necessity for using very high doses of reagents, however, to detect in vitro phosphorylation of membranes, is well recognised. EGF itself is used, by others ${ }^{37}$ as well as ourselves, at doses 100 to 1000 times that used for inducing DNA synthesis in cell cultures, because the phosphorylation is not readily detectable at a lower dose. The high dose of TAGH, when used in the cell culture system, did not induce DNA synthesis, but in contrast there was a substantial decrease (by greater than $90 \%$ ) in amino acid incorporation into protein (data not shown), showing that at those concen- trations there was local toxicity to the whole cell. It seems, however, very unlikely that 'toxicity' to isolated membranes could induce the specific tryosine phosphorylation of the EGF receptor that we have shown.

If TAGI can cause EGF receptor phosphorylation not only in isolated liver cell membranes, but in vivo, this may constitute the mechanism by which it stimulates DNA synthesis. TAGH might be acting by enhancing the effect of the physiological levels of ligands of the EGF receptor in the hepatocyte environment by phosphorylation of the EGF receptor. Our cell culture experiments do not support this suggestion as they did not show the synergy between EGF and TAGH that would be predicted, but because of the inhibitory effect of TAGH alone at the concentrations used, they cannot refute this possibility.

As a direct interaction of a component of TAGH with the EGF binding site on the receptor is not apparent, the mechanism by which TAGH leads to EGF receptor phosphorylation is unclear. It is possible that the tyrosine phosphorylation caused by TAGH is not autophosphorylation of the receptor - that is, by activation of the receptor's own tyrosine kinase, but is induced by other tyrosine kinases. Whether the tyrosine phosphorylation pattern of the receptor in response to TAGH is the same as that caused by EGF or TGF $\alpha$ was not investigated. Different sites or patterns of phosphorylation might be expected to result in different secondary events within the hepatocyte. Further consideration of this would also require elucidation of whether TAGH induces similar phosphorylation of the receptor in vivo as occurs on membranes in vitro.

It is possible that the striking proliferative events started by TAGH in vivo reflect secondary actions of TAGH. TAGH might stimulate formation or release of EGF from duodenum, submaxillary glands, or platelets, or stimulate TGF $\alpha$ synthesis or release in the intact liver. This second possibility is under investigation.

This work was supported by grants from The Medical Research Council and the Cancer Research Campaign.

1 Michalopoulos GK. Liver regeneration: molecular mechanisms of growth control. FASEB ₹ 1990; 4: 176-87.

2 Earp HS, O'Keefe EJ. Epidermal growth factor receptor number decreases during rat liver regeneration. $\mathcal{F}$ Clin Invest 1981; 67: 1580-3.

3 Rubin RA, O'Keefe EJ, Earp HS. Alteration of epidermal growth factor-dependent phosphorylation during rat liver regeneration. Proc Natl Acad Sci USA 1982; 79: 776-80.

4 Wollenberg GK, Harris L, Farber E, Hayes MA. Inverse relationship between epidermal growth factor induced proliferation and expression of high affinity surface epidermal
growth factor receptors in rat hepatocytes. Lab Invest 1989; 60: $254-9$.

5 Gladhaug IP, Christoffersen T. Rapid constitutive internalization and externalization of epidermal growth factor receptors in isolated rat hepatocytes. F Biol Chem 1988; 263: 12199203 .

6 McGowan JA, Strain AJ, Bucher NLR. DNA synthesis in primary cultures of adult rat hepatocytes in a defined medium: effect of epidermal growth factor, insulin, medium: effect of epidermal growth factor, insulin,

7 Okamoto M, Karasik A, White MF, Kahn CR. Epidermal growth factor stimulates phosphorylation of a 120 -kilodalton endogenous substrate protein in rat hepatocytes. Biochemistry 1990; 29: 9489-94.

8 Short J, Brown RF, Husakova A, Gilbertson JR, Zemel R, Lieberman I. Induction of deoxyribonucleic acid synthesis in the liver of the intact animal. $\mathcal{F ~ B i o l ~ C h e m ~ 1 9 7 2 ; ~ 2 4 7 : ~}$ 1757-66. 
9 Higgins GM, Anderson RM. Experimental pathology of the liver. I. Restoration of the liver of the white rat following partial surgical removal. Arch Pathol 1931; 12: 186-202.

10 Munro HN, Fleck A. The determination of nucleic acids. Methods Biochem Anal 1966; 14: 113-76.

11 Vesey DA, Woodman AC, Hodgson HJF. Galactosamineinduced hepatitis involves a reduction in hepatocyte epidermal growth factor receptors. Gut 1992; 33: 954-8

12 Berry MN, Friend DS. High yield preparation of isolated rat liver parenchymal cells: a biochemical and fine structural study. F Cell Biol 1969; 43: 506-20.

13 Aronson $\mathrm{NN}$, Touster $\mathrm{O}$. Isolation of rat liver plasma membrane fragments in isotonic sucrose. Methods Enzymol 1974; 31: 90-102.

14 Schacterle GR, Pollack RL. A simplified method for quantitative assay of small amounts of protein in biological material. tive assay of small amounts of proch
Anal Biochem 1973;51: 654-5.

15 Vesey DA, Cunninghan JM, Selden AC, Woodman AC, Hodgson HJF. Dimethyl sulphoxide induces a reduced growth rate, altered cell morphology and increased EGF binding in Hep G2 cells. Biochem f 1991; 227: 773-7.

6 Selden C, Hodgson HJF. Further characterisation of hepatotropin, a high molecular weight hepatotropic factor in rat serum. f Hepatol 1989; 9: 167-76.

17 Bucher NLR, Patel U, Cohen S. Hormonal factors and liver growth. Adv Enzyme Regul 1978; 16: 205-13.

18 Marti U, Burwen SJ, Jones AL. Biological effects of epidermal growth factor, with emphasis on the gastrointestinal tract and liver: an update. Hepatology 1989; 9: 126-38.

19 Brenner DA, Koch KS, Leffert HL. Transforming growth factor- $\alpha$ stimulates proto-oncogene c-jun expression and a mitogenic program in primary cultures of adult rat hepatocytes. DNA 1989; 8: 279-85.

20 Mead JE, Fausto N. Transforming growth factor- $\alpha$ may be a physiological regulator of liver regeneration by means of an physiological regulator of liver regeneration by means of an autocrine

21 Massague J. Transforming growth factor- $\alpha$. A model for membrane-anchored growth factors. F Biol Chem 1990; 265: 21393-6. 